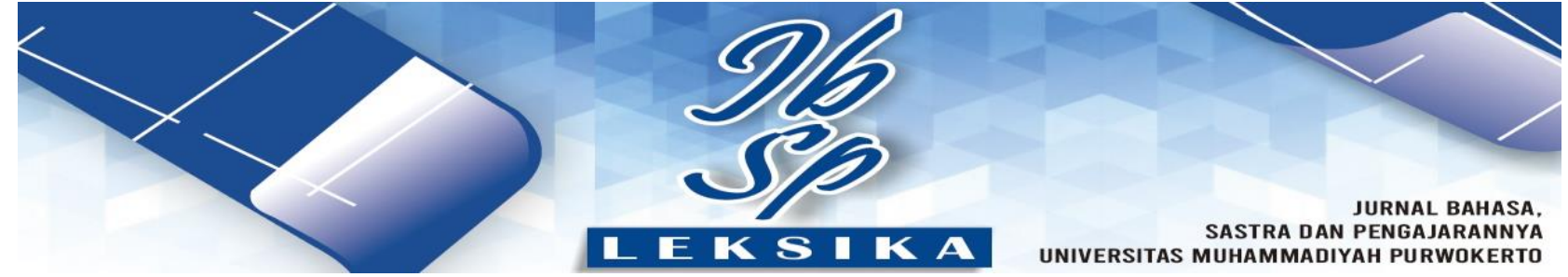

\title{
Women economic participation in novel Tentang Kamu by Tere Liye
}

\author{
Fikha Nada Naililhaq ${ }^{1}$, ${ }^{*}$ Wening Udasmoro² \\ ${ }^{1}$ Magister Ilmu Sastra, Fakultas Ilmu Budaya, Universitas Gadjah Mada, Yogyakarta, Indonesia. \\ ${ }^{2}$ Fakultas Ilmu Budaya, Universitas Gadjah Mada, Yogyakarta, Indonesia.
}

\begin{abstract}
The issue of the women's role in the public sphere has been widely carried out in literary research. However, research on women's participation specifically on economic issues by looking at its theoretical and empirical aspects is still something that is very rarely carried out in literary research. The purpose of this study is to explore in more detail about women's participation in the economy. By using the lens of women's thinking and their participation in the economic field in the concept of women economic participation from Jacqui True, this research focuses on this issue. The method used is analyzing the content of the story that has been done by collecting data by collecting words, sentences, paragraphs related to women's participation in the economy. Furthermore, the data that have been found are analyzed using descriptive analysis methods. The descriptive method of analysis was carried out in several stages. The first stage is data collection which is done by collecting the aspects of women's participation in the economy in general in the data table. From the data table, it is classified according to the economic participation patterns found. The next stage is data analysis by dialogue data from the novel with the theory of women's participation in the economy. The results of this study indicate that women are able to get out of the crisis with their own efforts and hard work. Women also have an important role in the economic sector because they are able to create their own business opportunities so that they can improve their life.
\end{abstract}

Keywords: women's role, economy, Tentang Kamu, Tere liye

Article history: Recieved 27 Nov 2020, Final revision 7 Feb 2021, Published 28 Feb 2021

\section{Introduction}

Research on women's participation in the public sphere, especially in the economic sector, is still very rarely carried out, especially in literature. Several literary works raise female figures that have an important role in the economic field. Udasmoro (2017) said that the role of women in the domestic field is continuously reproduced in daily life, including in literary works. This shows that women's participation in the public sphere especially in the economic field needs more deeply discussed because many literary works have strong aspects to understand the role of women. In fact, Indonesian women have had enough representative roles in the economic sector for a long time. However, in the context of the New Order, women's work was then used to legitimize and support men's work (Udasmoro, 2009). Thus, it raises the injustice received by women, especially regarding their role in the economic sector.

There are some studies have been conducted to analyze the novel. Several previous studies that discuss the role and position of women in society. There are some studies have been conducted to analyze the novel. Several previous studies that discuss the role and position of women in society. Some researches discusses about woman stereotype from occupation, wisdom, feminism and moral friction point of view in the novel Tentang Kamu using different feminist perspective (Naililhaq, 2019; Setiawan, 2018). Both argues that the female character on the novel shows resilience and determination in contesting the patriarchal culture within the society. Other researches focus on the main character's, Sri Ningsih, social imaginary (Lusiana, 2018) and inner conflict (Mayangsari, 2018), arguing that Sri Ningsih characterization is contested based on both her physical, social and psychological attribute.

However, it appears that no one has discussed women's participation in the economic field, especially in literary research. Even though this aspect is often being the focus of literary authors. For example, in Tere Liye's novel Tentang Kamu, clearly represented the participation and role of women in the economic field. Tentang Kamu describes the life story of a woman named Sri Ningsih who comes from Bugin Island, Sumbawa. She lives alone because her parents and younger

*Corresponding author: Wening Udasmoro, Faculty of Cultural Sciences UGM, JL Nusantara 1 Bulaksumur Yogyakarta 5528, email: udasmoro@ugm.ac.id 
brother had died. Since child, Sri worked diligently to survive. Sri likes challenges and liked to try new things proven by her migration to Jakarta to change her destiny. She looks for business opportunities to enter the world of economy. Historically, for a woman to enter the public sphere is not easy. Women must go through the mindset that has trapped them, especially those stating that jobs suitable for women are only related to the domestic field, while the public sphere is only for men. The position of men is assumed to be a patron that forces women to continue depending her economy on men and completely surrender their fate to men (Nasiru, 2017).

The position of women is considered as subordinate to men, so that men feel that they can act arbitrarily towards women. According to Beauvoir (2015) men are Sang Diri (The Self) who can occupy a central position, while women are Sang Liyan (The Other), whose existence is not important. Women are considered unable to account for themselves, unlike men who are able to have their bodies freely (Tong, 2006). By deploying herself on economic bargaining position, women are able to actualize and express themselves (Putri, 2020).

The existence of differences in positions between women and men results in social jealousy because women cannot fully obtain their rights. They are shackled in the power of men who always oppress them. The shackles of male power keep them in the domestic field because this field is considered more suitable for women who have a big role in reproduction. Meanwhile, men act as the main breadwinners in their families whose jobs are in the public domain. The difference between men and women makes women as subordinate beings who do not have a strong enough position in household life (Abdullah, 2001). This has resulted in various forms of injustice, such as marginalization or the process of economic impoverishment, subordination or the perception of insignificance in political decisions, and the formation of stereotypes or through negative labeling, violence (Fakih, 2010). Injustice also makes it easier for men to oppress women. Women's oppression is related to race, class, sexual preference, education, job opportunities, and so on (Mustika, 2016).

The theory about the role of women in the public sphere, especially in the economic sector, was carried out by Jacqui True (2012) in his book entitled The Political Economy of Violence against
Women. This theory questions the position of women who never get the same socio-economic rights as men. Even access to economic sectors related to productive resources is being complicated, in contrast to men who easily get jobs in the public sphere. True (2012) states that the existence of economic globalization provides few opportunities for women to enter the economic field, however, the positions obtained between men and women are different. Many women are positioned as workers in the informal sector, for example, such as factory workers. Meanwhile men have higher positions, namely important positions in a company. This shows that there is an agreement between the authorities and men to keep women in an inferior position (Ilma, 2016).

Feminist political economy understands gender relations from a social perspective that has been built historically, not just individual characteristics or behavior. Meanwhile gender is born through the structure of the economy and other sectors (Udasmoro, 2018). This makes gender a structure that supports and disrupts the economic paradigm and global governance. Globally, gender greatly affects economic activity, both during times of crisis and economic improvements (True, 2016). Thus, the role of women is also needed in the economic field, especially when making decisions. The presence of women in the economic field is used as a balancer to men's thinking so that decisions can be made wiser and more impartial.

The role of women in the public sphere is an option, but the fact that there are many women in the public sphere is still much debated. Women in the public sphere mean that there is a desire to change their destiny by becoming independent women. This kind of woman has more advanced thinking and it is certain that she is able to break through the economic capitalism that has been trapping her. This kind of cases are the focus of research in Tere Liye's novel Tentang Катu. Sri Ningsih is a female figure who was able to move out of the domestic sphere into the public sphere, especially the economic sector. Sri succeeded in building business opportunities and managed them to become a promising business. Sri is a figure of a woman who is independent and able to create her own business without any help from anyone. Even Sri was able to create jobs for other people from the business that she started from scratch. This paper will explore in depth about first, the underlying reasons why women are 
described as being able to build their own economy and the form of women's roles in the

\section{Research Method}

The analysis makes Tere Liye's novel Tentang Kamu as material object. Meanwhile, the formal object uses the concept of women's participation in the economic sector carried out by Jacqui True (2012). The analysis in this paper also uses certain methods and theories to assist in the data analysis process. The data collection methods and techniques used in this study are the analysis of the contents of the story, in this case, the participation of women in the economy. The data

\section{Results \& Discussion}

The results of this study describe the reasons underlying women are able to build the economy and the form of women's role in the field of economics found in the novel Tentang Кати by Tere liye. The following will be described in this regard.

\section{Women's economic field}

The decision of women to enter the world of economy is one of the major decisions that greatly affects their life. This method is used by women at the same time to explore the fate of women who have been framed in the domestic field without having the opportunity to contest in the public sphere (Udasmoro, 2015). Women have several strong reasons when they decide to enter this sphere. Sri's main reason for entering the economy is to help her family's economy, especially after her father died. Some literature also states that women who work in the public sector are always linked with their economic situation of the household (Tuwu, 2018). The public sphere, especially in the economic sector, is very prone for women to get unpleasant actions such as violence, whether sexual violence or discrimination in their position or position with men (True, 2012, 2016). This proves the toughness of women if they are able to go through the process and survive or even create their own business opportunities.

In Tere Liye's novel Tentang Kamu, the character Sri Ningsih has successfully entered the world of economics. Sri began to enter the world of economics after the die of her father. She became the backbone breadwinner of the family to support her mother and her baby brother. She did any work as long as it makes money, anything economic field that contained in Tere Liye's novel Tentang Катu.

were collected by collecting words, sentences, paragraphs related to women economic participation the topic. After collecting the data, the data was selected in a data table by grouping it into similar patterns. Then the data analysis method used is the descriptive analysis method, which has been done by describing the facts. It was then followed by an analysis that provides an understanding and explanation with the concepts from True's perspectives.

she could do. This idea refers to the following data.

Sri menggeleng perlahan. Dia tidak bisa pulang jika embernya belum penuh, dia tidak tahu harus sampai jam berapa. Satu tahun sejak kepergian bapaknya, bukan hanya harus membantu pekerjaan rumah, mengepel, mencuci, menyetrika, memasak, dia juga harus bekerja mencari uang. Mencari teripang, kerang atau tatahe (bulu babi) di laut dangkal sekitar Pulau Bungin adalah pekerjaan itu . (Tere-Liye, 2016)

Sri shook her head slowly. She could not go home if the bucket was not full, she did not know what time it would be. A year since her father died, not only had she had to help the task at home: mopping, washing, ironing, and cooking, she also had to work to earn money. She looked for sea cucumbers, clams or tatahe (sea urchins) in the shallow sea around Bungin Island. (my translation)

Sri Ningsih had to work hard to the bone in order to fulfill her family life. She worked by collecting sea cucumbers, shellfish or sea urchins in the shallow sea, but even though it was shallow, Sri still had to be careful because she was constantly being hit by the waves. In doing this work, Sri must optimize all the senses she had, especially her sight in order to keep an eye on her prey in the midst of the waves. The work she did is not an easy job, it was a big risk for a small woman like her. Sri had to stand constantly exposed to the heat, the waves and sometimes the rain hit her too. Sri Ningsih continued to do this routine without complaining, she even enjoyed her job. After her farming was sufficient, Sri sold it to collectors. Using that money, she bought her daily necessities like rice and side dishes. 
The role of women in the economic sector carries various risks among of which is violence. This shows when Sri Ningsih did the work alone after the death of her father because her mother still experienced grieve. She was only able to take care the baby. It was also common for Sri to receive capital punishment from her mother, such as beatings or insults. However, Sri accepted it sincerely without arguing. True (2012) supports this phenomena by arguing that violence to women occurs more often when she begins to actively participate in the public sphere, especially in the economy. Whereas before women enter the public sphere, they also possibly experience domestic violence from their husbands or families. When entering the economic field, women put themselves in a violence pit. Colleagues, bosses, superiors, or other people they do not know may inflict the violence on them in various form. Mustika (2016) also support this claim that women usually fall into systemic discrimination in the work place because of patriarchal culture. She emphasizes that the discrimination is also contested based on the gender, race and social status that are attributed to Sri Ningsih, representing women who have participated in the public sphere and experienced violence from their families, for example her own mother. Her mother would attack her daughter physically or verbally whenever the money she received does not suffice her daily necessities.

Sri continued to keep doing her daily activities passionately in collecting sea cucumbers, shellfish and sea urchins. Besides, she had to handle her domestic duties as a girl in the household such as mopping, washing, cooking, etc. Women who successfully enter the world of economy and continue to carry out their duties in the domestic field are said to be "new women" (Udasmoro, 2018). It means that because she is a tough woman, she can perform her jobs in two different domains. The entry of women into the public sphere means that women are able to accept the various consequences and demands they have to live with. The most important demand is that when women have actively participated in the public sphere, they cannot leave their domestic work, creating a double burden for her (Intan, 2014). They are required to be able to carry out two roles in different domains.

\section{Hardworking Women as an economic participation}

Sri Ningsih decided to move to Java after her family died in a fire. She chose to go to Surakarta and studied at a boarding school. But, she only study there for a very short period of time. After she had enough provisions, she continued her life journey by migrating to the capital city of Jakarta where she started a new chapter in her life. Previously, she worked to support her mother and younger brother, now she worked to support herself. Sri had a will to become a successful entrepreneur to help the financing her boarding school. The emergence of a willingness in women to play a role in economic life has indicated that there is already awareness to gain equality in the world of work. True (2016) argues that the role of women in the economic sector is very important to balance men's thinking in decision making.

In the early life in Jakarta, she tried to collect money by doing menial tasks. At first, she could not find any job. This situation then forced her to spend her savings. Then, she decided to go to the market to find any job there. She ended up being a blue collar worker to support her life while in Jakarta. Her decision to move to Jakarta is affected by the globalization of the economy that gives a women's access to participate in economic bargaining arena, making her easier to work in the public sphere (True, 2012). Sri Ningsih has to follow the globalization and the changes of technology since she is a teacher. She needs to adapt with that global changes. As a blue collar worker, she face sometimes the problems related to technology because with the faster technological system forces her to work harder. She is able to get any job, although it is identical to a man's job (Intan, 2014). Women start their life to get justice and equality with men, as it is stated in the narration below.

Tiga bulan berlalu, aku semakin cemas, tabunganku sudah sangat mengkhawatirkan. Lebihlebih aku sakit di awal bulan itu. Separuh semangatku runtuh. Kadang aku berpikir, mungkin sebaiknya kembali ke Surakarta. Tapi keinginan mencoba hal baru, melakukan hal-hal baru, membuatku kembali meneguhkan niat, siapa tahu akhirnya ada jalan. Setelah sembuh, sambil mencari pekerjaan tetap, aku bekerja serabutan di pasar agar dapat bertahan lebih lama. Menjaga kios, dan menjadi kuli angkut. Aku memikul karung beras, disuruh ini itu, dan apa saja sepanjang bisa makan. (Tere-Liye, 2016) 
Three months passed, I became more and more anxious, and my savings becomes more and more limited. Moreover, I was sick at the beginning of that month. Half of my spirit collapsed. One time, I thought, "maybe I should go back to Surakarta". But the desire to try new things, to do new things, made me reassert my mind, who knew in the end there was a way. After being recovered, while searching for a permanent job, I did casual jobs in the market so I could survive longer. I looked after the shops, and I became porter. I carried sacks of rice, I was told to do this and that, and anything as long as I could eat. (My translation)

The above quote shows how difficult it is for her to find a job in a big city. Her promising image of the city just disappears as she arrives there and the job is difficult to find. However, she does not give up, she accepts every hustling occupation that she can find. People are underestimated her work, but she does not want to bother and continues to enjoy every minute of her work. The entry of women into the public sphere still gets various kinds of debate, even though women's participation in the economic sector has actually existed for a long time. Some jobs are considered unsuitable for women. It is not uncommon for women to be described as passive and obedient (Adji, 2017). Women are also considered physically weaker than men. This causes bias against women and their activities or their work (Setyobudi \& Alkaf, 2012). Meanwhile, men are called the dominant class who are able to have greater access to jobs and get more adequate resources (Johnston, 2018).

According to Sri Ningsih, the job as a blue collar worker was less promising. She tried to find another more stable job even though she continued to do her daily menial job. Other than being a porter, sometimes she got an offer to look after the shop. Thanks to studying at schools and Islamic boarding schools, it made her capable at basic reading, writing, arithmetic, and speaking foreign language. Even though she had more knowledge than market people, she still worked happily. After being a blue collar worker in the market for a long time, finally she found a new job vacancy as a teacher. This is in accordance with the following data.

Kabarku di Jakarta begitu-begitu saja. Pagi hari mengajar di SR, sore dan malamnya bekerja di kios pasar Tanah Abang. Aku sempat gugup ketika beberapa minggu lalu ada muridku yang ikut orang tuanya ke pasar, dia melihatku heran sedang mengangkut-angkut karung goni. Besoknya, kabar itu menyebar di sekolah, aku dipanggil kepala sekolah. Tapi syukurlah, tidak jadi masalah serius, aku hanya harus menjelaskan, mereka mungkin tidak terbiasa melihat guru wanita jadi kuli. (TereLiye, 2016)

My life condition in Jakarta was just ordinary. I taught at SR in the morning, in the afternoon and at night I worked at the Tanah Abang market stall. I was nervous a few weeks ago when a student of mine went to the market with he parents, he was surprised watching me carrying gunny sacks. The next day, the news spread at school, I was called by the principal. But thank God, it did not really matter, I just had to explain, they might not be used to seeing female teachers became blue collar worker. (my translation)

The quotation above shows that Sri has found a new more authoritative job, which was becoming a teacher at Sekolah Rakyat (SR). She teaches at SR every day from morning to noon. When she first becomes a teacher at SR, she decides to cease her job at the market, but gradually Ashe feels bored just staying in the boarding house from day to night. Finally, she decides to continue to accept menial jobs in the market. From the morning to midday, she becomes a teacher at the SR, then she takes menial job in the market for the rest of the day. Sri experiences all of her work happily. She is determined and enthusiastic to work so that she can start her own business.

Once, Sri met her students at the market. The student was shocked to see his teacher took such a hustling job, and so was the school. The school principal called Sri Ningsih, but the principal understood her condition and they allow her to continue to work at the market. She is never ashamed for what she does. For Sri Ningsih, the most important thing is that her occupation is legal and does not violate the existing norms in society. However, in Indonesia, teacher and menial job in the market have a striking difference. Teachers are synonymous with people who are highly educated, authoritative, and have broad insight. Meanwhile, the menial job in the market is identical with people who is uneducated and have a rough background.

After working very hard, she feels that her savings are enough to be used as business capital. 
She is looking for business opportunities by thinking carefully about her new business, such as calculated her capital properly. The desire of women to open their own businesses indicates that there is a desire to be a leader to become a superpower whose function is to prove that women are able to manage business and become leaders in their business. This proves that women are able to take on social and economic roles like those of men (Kusmana, 2015). The following is an excerpt from the data that shows this.

Setahun menabung, uangku sudah cukup untuk memulai usaha. Aku berpikir jika aku bisa membuat alat yang mudah dibawa ke mana-mana, maka aku bisa berdagang tanpa harus punya warung. Alat yang cukup besar untuk membawa keperluan, karena kalu digendong atau dipikul dengan bilah bambu, itu tidak mungkin. Bebulan-bulan aku memikirkannya, kemudian mulai merancang gambar kasarnya di kertas. Aku menemui tukang kayu dan montir bengkel motor, menunjukan rancangan itu. (Tere-Liye, 2016)

A year of saving, I had enough money already to start a business. I thought that if I could make a tool that was portable, then I could sell without had to have a shop. A large enough tool to carried necessities, because if it was shouldered or carried with a bamboo blade, it would not be possible. I thought about it for months, then I started to draft the rough drawings on paper. I went to see a carpenter and motorbike repair mechanic, to showed my design. (My translation)

The data quotation above shows that Sri has prepared her business in detail. In pioneered her business, Sri makes the observations of her surrounding environment. She has already acquired a business mindset that she has to spend the fewest resource available while she can gather the most profit as possible. Finally, she finds the idea to sell the food using a cart. Using this method, she is able to work without renting a place, so she spend her lowest capital possible. She always calculates how much capital she spends. That was the economic principle that Sri followed in starting her business. She has proven that women do not only contribute in the domestic field, women are able to actively contribute in the economic field to improve their life (Rahayu, 2015).

After being a businesswoman for a long time, Sri was able to add to her cart. She increasingly expanded to the culinary world. She sold various kinds of food. Her business was increasingly successful. Until finally, many people followed her trail to sell using carts. Because the business competition of selling food in the carts became competitive, her income got lower. Sri decided to sell all of her carts and tried to open a new business. She believed that selling food around in carts was no longer promising because besides her many competitors, she also needed to deal with the Satpol PP, a municipal police who usually disciplines the illegal street merchant. In order to get the maximum benefit, women give up the business they have started and starting new, more promising businesses. In this case Sri Ningsih has the courage to make decisions that are difficult. The following quote mentions her willingness to start a new business.

Aku resmi memulai usaha baru, sewa mobil. Namanya "Rahayu Car Rental", aku sengaja memakai bahasa asing, karena target pasarannya mereka. Aku juga sengaja memilih mobil Jepang, karena walaupun taksi lain lebih banyak menggunakan mobil merk Amerika, mobil Jepang lebih hemat bensin, lebih mudah perawatan. Besok lusa merk ini akan mengalahkan merk Amerika. (Tere-Liye, 2016)

I officially started a new business, which is a car rental that I name it "Rahayu Car Rental". I purposely use foreign language because the target market was international tourist. I also purposely chose Japanese cars, because although other taxis use American cars, Japanese cars use fuel more efficiently and they are easier to maintain. One day, this brand would beat the American brand. (My translation)

The quote shows that Sri Ningsih has opened a new business in the transportation sector. She is a woman who possesses a high curiosity and courage in herself so that she is able to try new businesses without fear of failure. She is an intelligent person, in making decisions it was definitely considered carefully and seriously. She opens a car rental business targeting the foreign tourist market. In the selection of the car, she also considers the details. She chooses a car that is easy to maintain and saves on gasoline. The decision to choose a new business which is actually riskier indicates that women play an important role in controlling various sectors of the economy (Candraningrum, 2013). 
Due to her persistence in working, her car rental business ran smoothly. Sri added several kinds and types of cars to enlarge her business. Even though she was considered successful, she continued to work. She monitored her own office. Even when a driver was unable to arrive, she was willing to replace him as a driver. Sri Ningsih's success in the transportation sector did not last long, because at that time the Malaria disease occurred. Massive demonstrations by students and various groups were marked by the existence of arson, vandalism, and riots which result in several deaths and injuries (Jazimah, 2013). This can be seen in the following quote.

Tidak ada yang bisa aku lakukan di tengah kekacuan. Karyawan kantor harus segera diungsikan ke tempat lain, aku hanya bisa menyaksikan kantor terbakar dari kejauhan. Mobilmobil dibakar masa, mereka mengincar apapun yang bermerk Jepang. Delapan belas mobil itu tidak ada yang tersisa, enam terbakar di pool, sisanya terbakar dijalanan. Aku sedang di titik paling rendah. (Tere-Liye, 2016)

There was nothing I could do in the middle of a mess. Office employees must immediately be evacuated to another place, I could only watch the office got burnt from distance. The cars were burnt by the masses, they were after any Japanese brand. Eighteen cars were not left at all, six were burnt in the pool, and the rest were burnt on the road. I was at the lowest point. (My translation)

The quote above illustrates that everyone who has a business must be prepared for the possibilities that will occur. Just like what happened to her, she experienced the bad luck. All the vehicles she owned were Japanese brands. As a result, all of her belongings were burnt and destroyed by hundreds of demonstrators who brutally destroyed everything labelled "made in Japan". She saw her own cars being burnt by irresponsible hands. When women enters the economic sector, they must be able to accept the consequences, just like what Sri Ningsih experienced, they are required to be prepared to face injustice and violence (True, 2012) due to patriarchal system inherited in global economic system (Barragan, Erogul, \& Essers, 2018). A woman who is able to survive at the lowest position like Sri Ningsih proves that she has succeeded in maintaining her position to survive in the economic arena.
At first, Sri Ningsih falls into despair and hopelessness of all the misfortune that had happened to her. However, they did not last long because she has already possess a strong determination and mentality to remain calm and intuitive in the economic field in order to improve her life. She has to start a new chapter of her life because her previous vehicle rental car had already burnt to the ground, making her going bankrupt. Then, she started her new life by becoming a worker at a laundry soap company. This is according to the following data.

Kondisiku ternyata tidak buruk-buruk amat Nur, salah satu pelanggan mobil menawarkan pekerjaan padaku, bule dari Inggris. Dia kepala pabrik yang baru berdiri dua tahun di Pulogadung, dia sering menyewa mobilku dulu. Entah karena kasihan atau aku memang mencukupi syarat, setelah wawancara aku diterima di sana menjadi pengawas pabrik. Setidaknya bahasa Inggrisku baik, jadi aku bisa berkomunikasi dengan insinyur asing di sana. Pabrik itu memproduksi sabun cuci, boleh jadi yang digunakan di madrasah dibuat di pabrik ini. (TereLiye, 2016)

My condition was not that bad, Nur, one of the car customers offered me a job, a foreigner from England. She was the head of a factory that had only been established for two years in Pulogadung, she used to rent my car. Either because of pity or I did fulfill the requirements, after the interview I was accepted there to became a factory supervisor. At least my English was good, so I could communicate with foreign engineers there. The factory produced laundry soap, presumably the one used in the madrasah was made in this factory. (My translation)

The above quote shows that Sri Ningsih has found a job at a laundry soap company. She gets the job from her car customer, a foreigner from England. There, she works hard and diligently. She understands various methods to make laundry soap, from the selection of materials, processing, manufacturing, to marketing. She always pays a close attention and understands the process of making laundry soap carefully. In her observations, it crosses her mind to open a soap business. Every day she observes and communicates with other workers about obtaining materials or anything else. Until finally she believes that she gains enough capital by being a employee in a laundry soap company. The 
savings are enough to open a new business shown in the following data.

Aku punya modal untuk memulai usaha baru, Nur. Tidak dalam skala besar, tapi cukup. Aku akan membuat pabrik sabun. Aku tidak akan menyaingi pabrik tempatku bekerja, aku akan fokus pada sabun mandi. Aku tahu apa yang dibutuhkan konsumen. Pasar menengah Indonesia menginginkan sabun mandi yang lebih berkualitas, premium. Pasarnya telah tumbuh, lima enam tahun lagi akan lebih besar dibanding pasar Singapura. Aku sudah melakukan riset, termasuk mempelajari pola penjualan. (Tere-Liye, 2016)

I had the capital to start a new business, Nur. Not on a large scale, but sufficient. I was going to make a soap factory. I would not compete with the factory where I worked, I would focus on soap. I knew what consumers need. The Indonesian middle market wanted higher quality, premium bath soap. The market had grown, in five and six years it would be bigger than the Singapore market. I had done research, including studied the sales patterns. (My translation)

The data above shows that Sri Ningsih's tenacity pays off. She re-opens a new business, which is bath soap business. The soap that she produces is different from her previous company. While the company produces the laundry soap, she focuses on bath soap. She conducts market research before she starts her business. The research she carried out is more sophisticated than before. Her target becomes wider and she no longer targets certain areas. Due to of her hard work and persistence, she is able to produce a soap company which later became a big company in Indonesia.

When women survive the economic field with the various pressures and obstacles they face, it indicates that they have succeeded in the economic field. Especially when she can create her own business and able to open job field for other

\section{Conclusion}

In Tere Liye's novel Tentang Kamu, there was a figure of a female character named Sri Ningsih who was tough, hardworking and never gave up. Sri Ningsih was present as a representation of women who play an active role in the economic sector. Women have succeeded in going through a long process by moving from the domestic sphere to the public sphere. The reason why women people. Just like what Sri Ningsih did, she repeatedly falls but she did not give up. She continues to struggle until she achieves something she wants which by having her own company that becomes a big company in Indonesia shown on the following quotation.

Kerja keras tidak pernah mengkhianati, Nur. Tiga bulan sejak rilis pertamanya, sabun 'Rahayu' laris manis. Toko-toko yang dulu menolak menjualnya, sekarang mengirim pesanan. Supermarket, pusat perbelanjaan yang dulu enggan mendisplay produk itu, sekarang meletakkan di rak terdepan. Aku sekarang memikirkan kembali kapasitas pabrik, karena produksi sabun berkejaran dengan omzet penjualan. (Tere-Liye, 2016)

Sri Ningsih's hard work has been fruitful. Three months since she has started her new business, the soap "Rahayu" attracts many customers. The one who declines her product at first, now they send her the request. Supermarket and shopping center who hesitated to display the soap "Rahayu", now they display it on the first row. Now, I reflect back on my business capacity because the demand has caught up with the supply. (My translation)

Women are able to struggle and to survive in the public sphere because of the economic globalization that has provided opportunities for women to start fighting in the public sphere, especially in economic field (True, 2012). In this era, the capitalistic system allows women economic dependence to men being overshadowed, thus making them able to survive on her own. This is an indicator of women's bargaining position moving up towards the point of equality with men's bargaining position (Intan, 2014). Thus, women are able to equalize their positions with men, both in the form of roles, positions and jobs. This shows that Sri Ningsih has participated significantly in the economic field. Sri has also proven her existence to survive and compete in the agricultural sector.

participate in the economic sector is for the welfare of their life and families.

The form of women's participation in the economy can be seen from various perspectives. First, they are able to take advantage of job opportunities in accordance with the needs of society. Second, women can to create business 
fields for people. Third, women has the courage to make decisions that will greatly affect their life. Fourth, they have a capacity to think critically, work hard, and not easily give up.

The participation of women in the public sphere does create a new color in the world of

\section{References}

Abdullah, I. (2001). Seks, gender \& reproduksi kekuasaan. Yogyakarta: Tarawang Press.

Adji, A. N. (2017). Being a Sensible Woman: Hypertextuality in Grimm's Fairy Tale and Juliet Marillier's Wildwood Dancing. Poetika: Jurnal Ilmu Sastra, 5(2), 109-122. https://doi.org/10.22146/ poetika.v5i2.264 33

Barragan, S., Erogul, M. S., \& Essers, C. (2018). 'Strategic (dis)obedience': Female entrepreneurs reflecting on and acting upon patriarchal practices. Gender, Work \& Organization, 25(5), 575-592. https://doi.org/10.1111/gwao.12258

Beauvoir, S. de. (2015). The Second Sex. London: Vintage Classic.

Candraningrum, D. (2013). Superwoman syndrome dan devaluasi usia: Perempuan dalam karier dan rumah tangga. Jurnal Perempuan, 18(1).

Fakih, M. (2010). Analisis gender dan transformasi sosial (T. Rahardjo, Ed.). Yogyakarta: Pustaka Pelajar.

Ilma, A. A. (2016). Representasi Penindasan Ganda dalam Novel Mirah Dari Banda; Perspektif Feminisme Poskolonial. Poetika: Jurnal Ilmu Sastra, 4(1), 3-9. (Novel). https://doi.org/10.22146/ poetika.v4i1.133 10

Intan, S. (2014). Kedudukan Perempuan dalam Domestik dan Publik Perspektif Jender (Suatu Analisis berdasarkan Normatifisme Islam). JURNAL POLITIK PROFETIK, 2(1). https://doi.org/10.24252/ profetik.v2i1a5

Jazimah, I. (2013). MALARI: Studi Gerakan Mahasiswa Masa Orde Baru. AGASTYA: JURNAL SEJARAH DAN PEMBELAJARANNYA, 3(01). https://doi.org/10.25273/ajsp.v3i01.902

Johnston, M. F. (2018). The political economy of gender interventions: Social forces, kinship, violence, and finance in postconflict Timor-Leste (Ph.D dissertation, Murdoch University). Murdoch University. economy. Moreover, women are able to do heavy jobs of the men. In their role in the economic sector, women are able to compete and realize their own existence. This is a concrete manifestation that women's abilities are not very different from the men's.

Retrieved from https://researchrepository.murdoch.edu.a $\mathrm{u} / \mathrm{id} /$ eprint/41181/

Kusmana. (2015). Menimbang Kodrat Perempuan antara Nilai Budaya dan Kategori Analisis. Refleksi, 13(6), 779-800. https://doi.org/10.15408/ref.v13i6.1000

Lusiana. (2018). Citra Perempuan dalam Novel Tentang Kamu Karya Tere Liye dan Novel Cermin Jiwa Karya S. Prasetyo Utama (Undergraduate Thesis, Sriwijaya University). Sriwijaya University, Palembang. Retrieved from https://repository.unsri.ac.id/15442/

Mayangsari, I. A. (2018). Konflik Batin Tokoh dalam Novel Tentang Kamu Karya Tere Liye: Kajian Psikologi Kurt Lewin. BAPALA, 5(2). Retrieved from https://jurnalmahasiswa.unesa.ac.id/inde x.php/bapala/article/view/27687

Mustika, M. (2016). Diskriminasi terhadap Beberapa Perempuan dalam Perspektif Feminisme Multikultural: Kajian terhadap Novel Scappa Per Amore Karya Dini Fitria. Poetika: Jurnal Ilmu Sastra, 4(1), 33-41. https://doi.org/10.22146/ poetika.v4i1.133 13

Naililhaq, F. N. (2019). Perlawanan Tokoh Sri Ningsih terhadap Stereotip Pekerjaan Perempuan dalam Novel Tentang Kamu Karya Tere Liye: Kajian Feminisme dan Implementasinya pada Pembelajaran di SMA. Repetisi, 2(1), 21-35. Retrieved from jom.untidar.ac.id/index.php/repetisi/articl e/view/767

Nasiru, L. O. G. (2017). Transformasi Perempuan dari "Liyan" ke "Diri" dalam Tiga Cerita Rakyat Kulisusu: Analisis Wacana Feminisme. Poetika: Jurnal Ilmu Sastra, 5(1), 26-35. https://doi.org/10.22146/poetika.v5i1.259 96

Putri, R. A. (2020). Dekonstruksi Girl Power dalam Novel The Devil Wears Prada Karya 
Lauren Weisberger. Poetika: Jurnal Ilmu Sastra, 8(1), 51-63. https://doi.org/10.22146/poetika.v8i1.565 40

Rahayu, A. W. (2015). Perempuan Dan Belenggu Peran Kultural. Jurnal Perempuan, 84. Retrieved from http://www.jurnalperempuan.org/7/post /2015/01/perempuan-dan-belengguperan-kultural.html

Setiawan, R. (2018). Subaltern, Politik Etis, dan Hegemoni dalam Perspektif Spivak. Poetika: Jurnal Ilmu Sastra, 6(1), 12-25. https://doi.org/10.22146/ poetika.v6i1.350 13

Setyobudi, I., \& Alkaf, M. (2012). Antropologi Feminisme dan Polemik Seputar Tubuh Penari Perempuan Jaipongan menurut Perspektif Foucault. Humaniora, 23(1). https://doi.org/10.22146/jh.1008

Tere-Liye. (2016). Tentang kamu. Jakarta: Republika Penerbit.

Tong, R. P. (2006). Feminist Thought: Pengantar Paling Komprehensif kepada Arus Utama Pemikiran Feminis (Kurniasih, Ed.; A. P. Prabasmoro, Trans.). Yogyakarta: Jalasutra.

True, J. (2012). Political economy of violence against women. New York: Oxford Univ. Press.
True, J. (2016). The Global Financial Crisis's Silver Bullet: Women Leaders and "Leaning In." In A. A. Hozic \& J. True (Eds.), Scandalous Economics: Gender and the Politics of Financial Crises. New York: Oxford University Press. Retrieved from 10.1093/acprof:oso/9780190204235.003.000 3

Tuwu, D. (2018). Peran Pekerja Perempuan dalam Memenuhi Ekonomi Keluarga: Dari Peran Domestik menuju Sektor Publik. AlIzzah: Jurnal Hasil-Hasil Penelitian, 13(1), $63-$ 76. https://doi.org/10.31332/ai.v13i1.872

Udasmoro, W. (2009). Pengantar Gender dalam Sastra. Yogyakarta: Fakultas Ilmu Budaya, Universitas Gadjah Mada.

Udasmoro, W. (2015). Paradoksalitas Pemosisian Perempuan dalam Novel Colomba Karya Prosper Mérimée. Jurnal Kawistara, $5(1)$. https://doi.org/10.22146/kawistara.6399

Udasmoro, W. (2017). Reproduksi Womanhood dalam Novel Bunda: Kisah Cinta 2 Kodi Karya Asma Nadia. Adabiyyāt: Jurnal Bahasa dan Sastra, 1(2), 182-200. https://doi.org/10.14421/ajbs.2017.01203

Udasmoro, W. (2018). Dari Doing ke Undoing Gender: Teori Dan Praktik Dalam Kajian Feminisme. Yogyakarta: UGM PRESS. 